\title{
Implementation of Motor Vehicle Whitening Program in the Technical Implementation Unit of Local Revenue Management (UPT PPD) Medan Selatan in 2018
}

\author{
Susi Hariyanti' ${ }^{1}$ Badaruddin $^{2}$, Abdul Kadir ${ }^{3}$ \\ ${ }^{1,2,3}$ Universitas Sumatera Utara, Indonesia
}

\begin{abstract}
National development is the government's effort in realizing the welfare of the people and the state, starting from increasing the standard of living of the community to improving the system for implementing state activities. National development is expected to be evenly distributed throughout the country, both centralized development and development in regions whose power is controlled by the regional government. Phenomenon In the Medan City area, motor vehicle tax is one type of regional tax collected by the Regional Revenue Service of the Province of North Sumatra through the Samsat Joint Office as one of the potential sources of tax revenue, where the Samsat Joint Office has an advantage in the number of vehicle taxpayers who continues to increase every year. From this phenomenon, should there be an increase in the ownership of motorized vehicles with a BK number (tax object) in the area of Medan City, it will have a positive impact on any increase in the amount of motor vehicle tax revenue at the Samsat Joint Office. But in fact, overall motor vehicle tax revenue at the Samsat Joint Office has not been fully realized easily, from the description above, researchers are interested in formulating the problem How to implement the 2018 motor vehicle tax bleaching program in the Regional Revenue Management Technical Implementation Unit (UPT PPD) Medan South and What are the obstacles to motor vehicle tax collection in 2018 in the Regional Revenue Management Technical Implementation Unit (UPT PPD) in South Medan. This type of research used in this study is a qualitative researcher.
\end{abstract}

Keywords taxes, tax bleaching, implementation

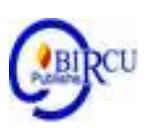

\section{Introduction}

National development is the government's effort in realizing the welfare of the people and the state, starting from increasing the standard of living of the community to improving the system for implementing state activities. National development is expected to be evenly distributed throughout the country, both centralized development and development in regions whose power is controlled by the regional government. During the implementation of this development, the government is always faced with various obstacles, one of which is the source of financing which plays a major role in the success of development itself (Bappenas, 2009). Meanwhile, according to Setiawan and Saefulloh (2019) that development is an effort to change to be better than the previous situation, consciously planned to be achieved in accordance with the objectives based on certain norms towards modernity gradually by utilizing the potential of natural, human and social and culture. 
Basically, the source of financing or state revenue consists of two parts, namely tax and non-tax revenue. Currently, state revenue from the non-tax sector is no longer reliable, for example from the oil and gas sector, which we know that from year to year the oil and gas sector has decreased so that the government has taken steps to optimize state revenue from the tax sector. Taxes are government achievements that are owed through general norms that can be enforced, without any counter-achievements that can be addressed in an individual case, the meaning is to finance government expenditures. One of the types of provincial taxes contained in Law Number 28 of 2009, namely Motor Vehicle Tax (Indah, 2005).

Governor Regulation Number 57 of 2018 Concerning the Granting of Motor Vehicle Tax Relief and Transfer of Motor Vehicle Title Fees for the Second (Second) Handover in North Sumatra Province. Given the large area of North Sumatra and many people who use motorized vehicles and the incomplete tax revenue in 2018, which is shown by the large number of taxpayers of around 5 million vehicles scattered and 4,344,234 million motorized vehicles have not paid taxes. That includes all types of vehicles, "said Victor Lumbanraja, Head of the Motor Vehicle Tax (PKB) Division, in his office, the North Sumatra Province Tax and Retribution Management Agency (BPPRD), Multipurpose Street, Helvetia, Medan City, (Tribun Medan, Wednesday (28/11/2018).

According to Rahmadan (2015), the phenomenon in the area of Medan City, motor vehicle tax is one type of local tax that is collected by the Regional Revenue Service of North Sumatra Province through the Samsat Joint Office as a potential source of tax revenue, which the Samsat Joint Office has excellence in the number of vehicle taxpayers which continues to increase every year. The increase in the number of taxpayers was motivated by the increasing number of ownership of motor vehicle tax objects with BK number plates in the Medan area from the number of names of motorized vehicles and the number of motorized vehicle purchases.

From this phenomenon, every increase in the ownership of motorized vehicles with a BK number (tax object) number in the area of Medan City will have a positive impact on any increase in the amount of motor vehicle tax revenue at the Samsat Joint Office. But in reality, overall motor vehicle tax revenue at the Samsat Joint Office has not been fully realized easily, even to the point of becoming one year tax receivables, five year tax receivables, and expired tax receivables. This is motivated by the compliance behavior of taxpayers who do not immediately pay off their payable taxes even though they have passed the tax period stipulated in the Motor Vehicle Registration Certificate (STNKB).

Based on the observations made by the researchers, the researcher found that there are several social phenomena related to awareness in the community regarding the payment of motor vehicle taxes and motor vehicle name transfer fees in the work area of the Regional Revenue Management Technical Implementation Unit (UPT PPD) in South Medan. This was revealed because researchers received information that in paying motor vehicle taxes and transfer fees on motorized vehicles, the public felt they still considered it expensive so that in general the public would wait for the motor vehicle tax bleaching program carried out by the government because it was considered cheaper. 


\section{Review of Literatures}

\subsection{Public Policy Theory}

Basically there are many limitations or definitions of what is meant by public policy (public policy) in political science literature. Each of these definitions emphasizes different things. This difference arises because each expert has a different background. Meanwhile, on the other hand, the approaches and models used by experts will ultimately determine how public policy is to be defined. (Winarno, 2007: 16).

The definition of public policy put forward by Thomas R. Dye (Syafiie, 2001: 16) states that "public policy is whatever the government chooses, whether to do something or not to do (silence) something (whatever government choose to do or not to do). ) "According to Syafiie (2001: 16), if the government makes a decision it must have a clear objective, and public policy includes all government actions, so it is not merely a statement of the desire of the government or government officials.

Meanwhile, Carl Friedrich in Winarno (2007: 17) argues that policy as a direction of action proposed by a person, group or government in a certain environment provides obstacles and opportunities for the proposed policies to use and overcome in order to achieve a goal or realize a specific goal or purpose. However, one thing that must be kept in mind in defining policy, is that defining policies must still have an understanding of what the government actually does, rather than what is proposed in action regarding a particular issue.

According to Winarno (2007: 18) argues that a more precise definition of public policy is as the definition put forward by James Anderson, namely "policy is a direction of action that has a purpose set by an actor or a number of actors in overcoming a problem or a problem". This policy concept is considered appropriate because it focuses on what is actually being done and not on what is proposed or intended by the government.

\subsection{Policy Implementation Theory}

In simple terms implementation can mean implementation or application. Majone and Wildavsky in Nurdin and Usman (2002), suggest implementation as evaluation. argued that implementation is the expansion of activities that are mutually adapting. The notion of implementation as an activity that adapts to each other was also put forward by Mclaughin in Nurdin and Usman (2002). As for Schubert in Nurdin and Usman (2002), argues that implementation is an engineering system. The definitions above show that the word implementation boils down to activity, the existence of an action, action, or mechanism of a system.

The expression mechanism implies that implementation is not just an activity, but an activity that is planned and carried out in earnest based on the reference to certain norms to achieve the objectives of the activity. Therefore, implementation does not stand alone but is influenced by the next object, namely the curriculum. In reality, implementation according to Fullan is a process of implementing a new idea, program or set of activities in the hope that other people can accept and make changes. In the context of curriculum implementation the approaches that have been stated above put emphasis on the process. The essence of implementation is a process, an activity that is used to transfer ideas / ideas, programs or expectations which are set forth in the form of policy implementation to be implemented in accordance with the design. Each of these approaches reflects a different level of implementation. 


\subsection{Definition of Tax}

Understanding Taxes Mardiasmo (2013: 17) says that taxes are contributions from the people that are given to the state treasury in accordance with applicable laws and can be enforced by not obtaining reciprocal services and taxes are used by the government to finance general state expenditures. In short, taxes are the transfer of wealth from the public to the state to finance routine expenses and the remainder is used for public savings, which are the main source to finance public investment.

Tax is a compulsory levy paid by the people to the state and will be used for the benefit of the government and the general public. People who pay taxes will not feel the benefits of taxes directly, because the tax is used for public purposes, not for personal gain. Taxes are one source of government funds for development, both the central and regional governments. Tax collection can be forced because it is carried out according to the law. (Siregar et al, 2019). Tax is a public contribution to the State treasury (transfer of private sector wealth to the law) based on the Act (can be forced) with no reciprocal services (tegen prestatie) which can be directly demonstrated and used to finance public expenditure (publieke uitgaven). (Marpaung, 2020)

Taxes can be used as a means to achieve certain goals of the government. Paying taxes is a state obligation carried out by taxpayers directly and jointly carrying out tax obligations for state financing and state development. Paying taxes is not just an obligation, but the right of every citizen to participate in the form of participation in state financing and development national. Tax from an economic perspective is defined as the transfer of resources from the private sector to the public sector and causes a reduction in individual control over their resources, but it can increase the state's financial capacity in the provision of public goods and services. Meanwhile, from a legal perspective, tax is defined as the existence of a bond because of the law that causes the state's obligation to arise which must be carried out by the community to deposit a certain amount of income to the state. The government has the power to coerce and the tax money must be used for government administration.

\subsection{Definition of Motor Vehicle Tax}

The large number of taxes that apply and are collected for the regions, one of them is the Motor Vehicle Tax (PKB). Regarding PKB, it can be stated as follows: Motor Vehicle Tax is included in the direct tax category and is a local (regional) tax. Collected from holders of motorized vehicles that are powered by a charcoal gas generator or, using kerosene fuel or a mixture of kerosene and gasoline or also, who do not solely use gasoline as fuel. Furthermore, in Law No. 28/2009, it is quoted as saying Motor Vehicle Tax, tax is levied because it holds:

1. A motorized vehicle driven by a motor that is powered by a charcoal gas generator or by using kerosene fuel or a mixture of kerosene and gasoline, regardless of whether the motor is specifically intended for use with kerosene or with a mixture of kerosene and gasoline;

2. All other motorized vehicles, which are not driven by a motor that solely use gasoline as fuel.

3. Motorized vehicles driven by motorcycles that solely use gasoline as fuel but have a total allowable weight of $5,500 \mathrm{~kg}$ or more and motorized vehicles driven by motor using only gasoline as fuel, which have a total allowable weight of $3,500 \mathrm{~kg}$ or more.

4. Motorized vehicles that have a total allowable weight of less than $3,500 \mathrm{~kg}$, except those that have been subject to household tax or are exempted from household tax. Paying attention to Motor Vehicle Taxes as explained by the two quotes above, several main standards can be drawn, including: 
(1) This tax is generated by the existence of a motorized vehicle owned.

(2) tax is collected from motor vehicle owners as taxpayers.

(3) determination of the amount of tax burden is based on the size outlined

(4) a motorized vehicle is seen as a complete and lunar entity

(5) tax year is the calendar year. (Article 8 paragraph 1).

In article 1 point 6 of Regional Regulation Number 4 of 2003 concerning Motor Vehicle and Water Vehicle Taxes, it is stated that the Motor Vehicle and Water Vehicle Taxes are called taxes on the ownership or control of motorized vehicles and vehicles traveling on water. Motorized vehicles are all two-wheeled vehicles or more and their trailers that are used on all types of land roads and driven by technical equipment in the form of a motorbike or other equipment which functions to convert a certain energy resource into the driving force of the motorized vehicle concerned, including heavy equipment. and large moving tools (article 1 point 7 ).

\subsection{Definition of Transfer of Motor Vehicle Title Fee Tax}

In addition to Motor Vehicle Taxes, there are sources of income related to motor vehicles. This source of income is called the Transfer of Motorized Vehicle Title Fee which is popularly abbreviated as BBNKB. This type of income source in the form of taxes is also collected on the basis of the transfer of title to a motorized vehicle as a result of a two-party agreement or unilateral act or conditions that occur in sale and purchase, exchange, grants including will and gifts, inheritance or income into a business entity.

The legal basis for the Transfer of Motor Vehicle Title Fee is Law No. 28/2009 concerning the Submission of State Tax on Transfer of Motor Vehicle Title Fee (BBN.KB), in article 9 it is stated that the Object of Transfer of Motor Vehicle Title Fee is the transfer of ownership of motorized vehicles, including in the meaning of Motorized Vehicle as referred to in paragraph (1) is a wheeled motorized vehicle and its trailer, which is operated on all types of land roads and motorized vehicles operated in water with a gross content size of GT 5 (five Gross Tonnage) up to GT 7 (seven Gross Tonnage). Article 9 also regulates the exemption in the collection of Motor Vehicle Title Fee tax.

2.6 Providing Motor Vehicle Tax Relief and Motor Vehicle Title Transfer Fee for Submission II (second) onwards in North Sumatra Province based on the Regulation of the Governor of North Sumatra No. 57 of 2018

The PKB and BBNKB relief grants as referred to in are given to Taxpayers who own 2 (two), 3 (three), 4 (four) wheels and so on, including Heavy Equipment Vehicles / Large Equipment. Dry PKB and BBNKB as intended, include:

a) $\mathrm{PKB}$ and $\mathrm{BBNKB}$ relief due to incoming mutations, namely relief provided to taxpayers who make incoming transfers from outside the Province of North Sumatra to the Region of North Sumatra Province;

b) $\mathrm{PKB}$ and $\mathrm{BBNKB}$ relief due to name transfer, namely relief provided to taxpayers who transfer ownership of motorized vehicles upon delivery II (Second) and so on;

c) Administrative Sanctions Relief, namely the provision of relief against the administrative sanctions that have been determined.

BBNKB relief on delivery II (Second) and so on, as referred to in PKB and BBNKB relief due to Transfer of Name, namely relief provided to taxpayers who transfer ownership of motor vehicles upon delivery II (Second) and beyond, excluding waivers for the calculation of imposition change shape; The relief as referred to applies if the taxpayer makes payments within the implementation time as referred to in the Granting of PKB and BBNKB 
Relief for Submission II (Second) onwards, implemented from 26 November 2018 to 28 December 2018.

PKB and BBNKB Relief as intended, namely the PKB and BBNKB Relief as referred to in the PKB and BBNKB Relief for Submission II (Second) onwards, implemented from 26 November 2018 to 28 December 2018 given to Taxpayers who own 2-wheeled motorized vehicles. (two), 3 (three) wheels, 4 (four) wheels and so on, including Heavy Equipment / Large Equipment Vehicles, including:

a) Principal exemption and administrative sanctions for the increase and / or interest on Transfer of Motor Vehicle Title Fee on Delivery II (Second) onwards;

b) Exemption from administrative sanctions for the increase and / or interest in Motor Vehicle Tax;

Whereas for the relief mechanism as intended, namely the PKB and BBNKB Relief as referred to in the PKB and BBNKB Relief for Submission II (Second) onwards, implemented from 26 November 2018 to 28 December 2018 given to taxpayers who own RCDA 2 motor vehicles (two), 3 (three) wheels, 4 (four) wheels and so on, including Heavy Equipment Vehicles / Large Equipment, provided provided that the Taxpayer submits and attaches:

a) Application in writing to the Governor of North Sumatra providing clear reasons;

b) Original KTP;

c) Valid vehicle ownership identity;

d) Public transport operating permit documents and route permits or non-route permits, for public transport motorized vehicles;

e) Letters or other evidence required in accordance with statutory provisions.

\section{Research Methods}

This research was conducted using qualitative research methods with data collection techniques through observation, interviews and documentation studies at the Regional Revenue Service Technical Implementation Unit (UPT PPD) Office of South Medan, Medan City, North Sumatra Province. The technique of determining informants using a purposive technique aims to expand the description of information and trace the variation of information that may exist, as well as to find out and review more deeply about the collaboration between stakeholders in the Regional Revenue Service Technical Implementation Unit Office (UPT PPD) Medan Selatan, Medan City, Sumatra Utara Province. The data analysis technique used in this research is analysis using the various categories seen in relation to one another and interpreted qualitatively.

\section{Result and Discussion}

The policy of the Governor of North Sumatra regarding the exemption of Motor Vehicle Tax administration sanctions in accordance with the Governor of North Sumatra Regulation Number 57 of 2018 concerning Governor Regulation Number 57 of 2018 concerning the Providing of Motor Vehicle Tax Relief and the Transfer of Motor Vehicle Title Fees for the Second (Second) Handover And So On In North Sumatra Province Based on the research results and in accordance with the established focus, the researchers can draw several conclusions, including:

Based on the established research focus, the researcher can conclude that the implementation of the Motor Vehicle Tax bleaching carried out by UPT DDP South Medan for name transfer duties is as follows: 
a) Communication to solve motor vehicle tax problems that have been identified and implemented well by fulfilling the dimensions of transmission (transmission), clarity (clarity) and consistency (consistency), so as to increase the regional revenue (PAD) of Medan city in the field of vehicle tax.

b) Human Resources to overcome motor vehicle tax problems that have been well identified with indicators 92 Human Resources, Orchid Resources and Authority Resources have been fulfilled, but the Equipment Resources indicator still has obstacles where when taxpayers overflow when doing their obligations they often face with limited service and payment facilities, namely the Payment Counter.

c) The disposition to overcome the problem of motor vehicle tax that has been identified still has obstacles where the implementation process takes place at UPT PPD Medan Selatan is not optimal where there is still a lack of close relationship between UPT PPD Medan Selatan and related regional government agencies that help the technical team causing service the licensing that was held by the UPT PPD Medan Selatan was a little troublesome in the optimization of services.

d) Organizational structure to overcome motor vehicle tax problems that have been identified still has obstacles. Where the problem for UPT PPD Medan Selatan is the lack of coordination and supervision so that brokering cases are rampant.

The obstacles faced by the UPT DPP Medan Selatan in implementing the bleaching program, namely:

a) Limitations of payment counters to handle accumulated taxpayers resulting in the emergence of brokering cases.

b) Public perception of the importance of motor vehicle tax payments is already good, but there are also those who make payments because they are afraid of the government and public perceptions about the bleaching program where taxpayers already understand and there are taxpayers who do not want to know about the bleaching program, this is not informed or communicated by the government regarding the outline of the use of taxes or even in Governor Regulation Number 57 of 2018 which only displays about the Granting of Motor Vehicle Tax Relief and Transfer of Motor Vehicle Title Fees for the Second (second) Submission of Taxes and so on in North Sumatra Province, and does not display or intended for the welfare of the people of North Sumatra

\section{Conclusion}

Based on the above conclusions, the authors write some suggestions, namely as follows:

1. To be able to improve the quality of licensing services maximally, the UPT PPD Medan Selatan should have a skilled and skilled workforce in the field of licensing services.

2. Preparing the means to anticipate taxpayers so that they do not become targets of brokers or unscrupulous individuals who offer shortcuts in services.

3. To increase resources in terms of quality, the employees of the UPT PPD Medan Selatan actively participate in education and training activities organized by the Government.

4. In the context of implementing the strategy, implementors with good capabilities are needed, the goal is that the strategies that have been created in such a way can be implemented optimally and are able to achieve the expected goals. 


\section{References}

Afifudin and Beni Ahmad Saebani. (2012). Qualitative Research Methodology, CV Pustaka Setia, Bandung.

Agus Dwiyanto. (2006). Realizing Good Geovernance through Public Services. UGM Press, Yogyakarta. (Bappenas, National Development Planning Agency. 2009. Equitable National Development, Bapenas, Jakarta.

Basrowi and Suwandi. (2008). Understanding Qualitative Research, Rineka Cipta, Jakarta Dwiyanto, Agus. 2012 (Volume Two). Public Bureaucratic Reform in Indonesia. Gadjah Mada University Press, Yogakarta.

Dunn, William N. (1998). Public Policy Analysis. Gadjah Mada University Press, Yogyakarta.

Edward III, George C. (1980). Implementing Public Policy. Washington: Congressional Quarterly Press.

Febriani, F. (2017). Analysis of Factors Affecting Motor Vehicle Tax Revenues With GRDP as Moderating Variable in North Sumatra. Thesis. Not Published.

Faculty of Economics and Business. University of North Sumatra: Medan.

Gibson, James L, 2001, Translation by Agung Wicaksono, 1997, Organization and Management; Behavior, Structure and Process. Erlangga, Jakarta.

Hogwood, Brian W, and Lewis A. Gunn, 1986, Policy Analysis for the Real World, Oxford University Press.

Indinisya Indah Pangalila and Ventje Ilat. (2015). Analysis of the Implementation of the Motor Vehicle Tax Collection System in the City of Manado. EMBA Journal, 3 (1).

Kirk, J. \& Miller, ML, 1986. Reliability and Validity in Qualitative Research, CA, Sage Publications, Beverly Hills.

Lisma, Deni. 2014. Implementation of Cross-Regional Motor Vehicle Tax Revenue (PKB) and Transfer of Motor Vehicle Title Fee (BBNKB), UT, Jakarta.

Mardiasmo. 2011 Revised Edition Taxation. Publisher Andi, Yogyakarta.

Nugroho, D. Riant. 2008. Public Policy For Developing Countries. PT Alex Media Komputindo, Jakarta.

Mardiasmo. 2013. Autonomy and Regional Financial Management. Andi, Yogyakarta.

Marpaung, A. (2020). Zakat Regulation as a Reduction of Income Tax in Indonesia. Budapest International Research and Critics Institute-Journal (BIRCI-Journal) Volume 3, No 3, August 2020, Page: 2109-2116. P. 2109-2116

Ramadan, Dian. 2015. Analysis of Motor Vehicle Tax Arrears at the North Medan Samsat Joint Office. UMA Medan. Rahayu, Siti Kurnia. 2009. Indonesian Taxation "Formal Concepts and Aspects". Yogyakarta: Graha Science.

Suandy, Erly. 2006. Taxation, First Edition. Jakarta: Four Salemba.Official, Siti. 2009. Taxation Theory and Cases. Selemba Empat, Yogyakarta.

Syafiie, Kencana, Inu. 2001. Introduction to Government Science (Revised 2001). PT. Refika Aditama, Bandung.

Santoso, Amir. 1993. Public Policy Analysis: An Introduction. Gramedia, Jakarta.

Setiawan, F. and Saefulloh, A.(2019). Collaboration carried out in the Kereng Bangkirai Jetty Tourism Area, Palangka Raya City. Journal of Administratio, 10 (2).

Siregar et al. (2019). The Effect of Corporate Taxpayer Compliance, the Increase of Corporate Taxpayers' Number and Tax Audits on Income Tax Receipts of Article 25 with Taxation Sanctions as a Moderating Variable in KPP Pratama Medan Petisah. Budapest International Research and Critics Institute-Journal (BIRCI-Journal). 385-400

Sugiyono, 2013. Quantitative Research Methods, Qualitative, and R \& D. Alfabeta, Bandung. 
Suhayati, Ely and Siti Kurnia Rahayu. 2006. Taxation "Theory and Technical Calculation". Graha Ilmu, Yogyakarta.

Suchman, Edward A. 1967. Evaluative Research: Principles and Practice in Public Service Action Programs. Russell Sage Foundation New York.

Usman \& Nurdin. (2002). Curriculum-Based Implementation Context. Jakarta: PT. Raja Grafindo Persada.

Usman Husaini \& Purnomo Setiady Akbar. (2008). Social Research Methodology. PT Bumi Aksara, Jakarta.

Authority, Samodra. (1994). Evaluation of Public Policy. Raja Grafindo, Jakarta.

Widodo, Budiharto. (2010). Robotics Theory and Its Implementation. Publisher Andi, Yogyakarta.

Winarno, Budi. (2005). Theory and Process of Public Policy. Media Pressindo (Member of IKAPI), Yogyakarta.

Winarno, Budi. (2007). Public Policy: Theory and Process. Yogyakarta: Med Press (Member of IKAPI).

Gunadi, Djoned. (2005). Tax Administration. Public Finance and Government Accounting Research Institute. Jakarta: Financial Education and Training Agency, Ministry of Finance of the Republic of Indonesia.

Other Sources:

Law No.28 of 2009 concerning Regional Taxes and Regional Retributions.

Regional Regulation of North Sumatra Province No. 1 of 2011 concerning Regional Taxes of North Sumatra Province.

Regional Regulation of North Sumatra Province No. 1 of 2015 concerning Amendments to the Regional Regulation of the Province of North Sumatra Number 1 of 2011 concerning Regional Taxes of the Province of North Sumatra.

Regulation of the Governor of North Sumatra Number 57 of 2018 concerning the Granting of Motor Vehicle Tax Relief and Transfer of Motor Vehicle Title Fees for Submission II (second) onwards in North Sumatra Province.

Regulation of the Governor of North Sumatra Number 89 of 2017 concerning the Granting of Motor Vehicle Tax Relief and Transfer of Motor Vehicle Title Fees on Delivery II (second) onwards in North Sumatra Province. 